\title{
A rapid immunoperoxidase assay for the detection of specific IgG antibodies to Chlamydia trachomatis
}

\author{
'R CEVENINI, F RUMPIANESI, M DONATI, I SAROV* \\ From the Institute of Microbiology, University of Bologna School of Medicine, Ospedale S Orsola, 9 Via \\ Massarenti, 40138 Bologna, Italy and *Department of Virology, Faculty of Health Sciences, Ben Gurion \\ University of the Negev, Beer Sheva, Israel
}

SUMMARY A technique, using indirect immunoperoxidase antibody (IPA), was developed for the detection of IgG antibody to Chlamydia trachomatis. The IPA technique employs glass slides with air-dried and acetone-fixed $C$ trachomatis infected cells, which can be stored at $-70^{\circ} \mathrm{C}$ and used for several months. Antibody titres detected by IPA were comparable to those detected by the indirect fluorescent antibody technique.

In recent years, the importance of $C$ trachomatis in sexually transmitted disease has been recognised, ${ }^{12}$ in addition to its long recognised role in trachoma. ${ }^{3}$

The diagnosis of $C$ trachomatis infections is generally made after isolation in cell culture, ${ }^{4}$ while the detection of chlamydial antibody in sera or local secretions is possible by other techniques. To date, microimmunofluorescence (MIF), ${ }^{5}$ is the most specific but it requires the availability of many serotypes of $C$ trachomatis and trained personnel. Efforts to simplify the test have involved the use of a single broadly reacting antigen, usually L2. ${ }^{6}$ Serotype $\mathrm{E}^{7}$ or serotype $\mathrm{L} 2^{89}$ have also been used in a single-antigen immunofluorescence antibody assay. Recently, ELISA ${ }^{1011}$ and RIA ${ }^{12}$ assays have also been used for the detection of antibody to $C$ trachomatis.

In the present study we have developed a simple immunoperoxidase technique for the detection of $C$ trachomatis IgG antibody; this was compared with the immunofluorescence antibody assay (IFA).

\section{Material and methods}

\section{CELLS AND MEDIA}

The LLC - MK2 cell line derived from monkey kidney cells was used. These cells (which we have found to be highly susceptible to $C$ trachomatis) were grown in $25 \mathrm{~cm}^{3}$ tissue culture flasks with Eagle's MEM with $10 \%$ fetal calf serum (FCS) and gentamicin $(10 \mu \mathrm{g} / \mathrm{ml})$. When a confluent monolayer had formed, the growth medium was replaced with

Accepted for publication 11 October 1982 the same medium containing $25 \mu \mathrm{g} / \mathrm{ml}$ of 5 -iodo-2' deoxyuridine (IUDR). After $72 \mathrm{~h}$, IUDRcontaining medium was discarded, the cell monolayers were washed twice with phosphate-buffered saline (PBS) and refed with Eagle's MEM plus 2\% FCS, gentamicin $(10 \mu \mathrm{g} / \mathrm{ml})$ and glucose $(30 \mu \mathrm{mol} / \mathrm{l})$.

\section{TRACHOMATIS ANTIGEN PREPARATION}

LLC-MK2 cell monolayers were infected with $C$ trachomatis serotype L2(434-Bu strain, provided by J Schachter, San Francisco, California). The infected cultures were incubated at $37^{\circ} \mathrm{C}$ for $48 \mathrm{~h}$. At that time, $60-80 \%$ of the cells showed the typical cytoplasmic inclusion, detectable by inverted microscope. The cells were removed from the flask with versene-trypsin solution, and washed with $0.01 M$ PBS, pH 7.4. Drops of twice-washed cell suspension, containing $10^{6}$ infected cells $/ \mathrm{ml}$ mixed with $2 \times$ $10^{5}$ uninfected cells $/ \mathrm{ml}$, were placed on glass slides and dried overnight at room temperature. Uninfected LLC-MK2 cells, prepared in the same manner, were used as controls. The slides were fixed in cold $\left(4^{\circ} \mathrm{C}\right)$ acetone, air dried, and stored at $-70^{\circ} \mathrm{C}$. The same antigen preparation was used for both the immunoperoxidase and immunofluorescence techniques.

IMMUNOPEROXIDASE ANTIBODY ASSAY (IPA)

The procedure has been described previously. ${ }^{13}$ Stored slides were thawed, washed in PBS and covered with test serum or control serum. After incubation at $37^{\circ} \mathrm{C}$ for $30 \mathrm{~min}$ followed by $15 \mathrm{~min}$ in PBS, the slides were incubated for $30 \mathrm{~min}$ with antihuman IgG peroxidase conjugate (Dako, 
Copenhagen, Denmark), 1/40 diluted in PBS. After washing, the enzymatic activity was detected using a modification of the method of Graham and Karnowsky. ${ }^{14}$ The freshly prepared substrate solution was made of $4 \mathrm{mg}$ benzidine (Fluka AG, Buchs, Switzerland), dissolved in $0.5 \mathrm{ml}$ acetone, $9.5 \mathrm{ml}$ PBS, and $10 \mu$ l hydrogen peroxide from a $33 \%$ stock solution. The substrate was added for $5 \mathrm{~min}$ at room temperature and was followed by PBS washing. A dark blue cytoplasmic stain of $C$ trachomatis inclusion was considered positive. Known positive and negative sera were included in each assay; the reproducibility of the titration was demonstrated by testing the same positive sera several times.

IMMUNOFLUORESCENT ANTIBODY ASSAY (IFA)

This was performed as previously described, ${ }^{15}$ but for the slides which were prepared as described above, instead of Lab-Tek (Miles Laboratories, Illinois) tissue culture chamber slides seeded with McCoy cells. Briefly, serial twofold dilutions of each sample of serum were placed on the slides and incubated for $30 \mathrm{~min}$ at $37^{\circ} \mathrm{C}$. The slides were then washed three times in PBS and dried. Fluoresceinconjugated antibodies to human IgG (Dako, Copenhagen, Denmark) were added, and the slides were incubated for $30 \mathrm{~min}$ at $37^{\circ} \mathrm{C}$, washed, counterstained with Evans' blue, mounted with glycerin and observed by a Zeiss UV microscope $(\times 400)$.

HUMAN SERA

Serum samples from 90 healthy men, and five convalescent sera of men with chlamydial non gonococcal urethritis (NGU), were tested.

\section{Result}

Fig. 1(a) shows the typical dark blue cytoplasmic staining of $C$ trachomatis LLC-MK2 infected cells, by peroxidase reaction. Cytoplasmic staining was absent on uninfected LLC-MK2 cells or when $C$ trachomatis-negative sera were examined (Fig. 1(b)). The use of peroxidase-conjugated antibody to human IgG at a dilution of 1/40 gave satisfactory results for specific determination of titres of antibody to $C$ trachomatis. Low levels of antibody to $C$ trachomatis were not detected with a conjugate dilution of 1/80. Fig. 2 shows the typical cytoplasmic fluorescence of LLC-MK2 cells infected by $C$ trachomatis.

Sera of 90 healthy men and five convalescent sera of men with chlamydial NGU were examined by both IPA and IFA. Fig. 3 demonstrates the comparison of IPA and IFA titres of sera from healthy adults and patients. Sixty-six sera were negative by both methods (titre $<1 / 8)$ and $24(26.6 \%)$ sera from

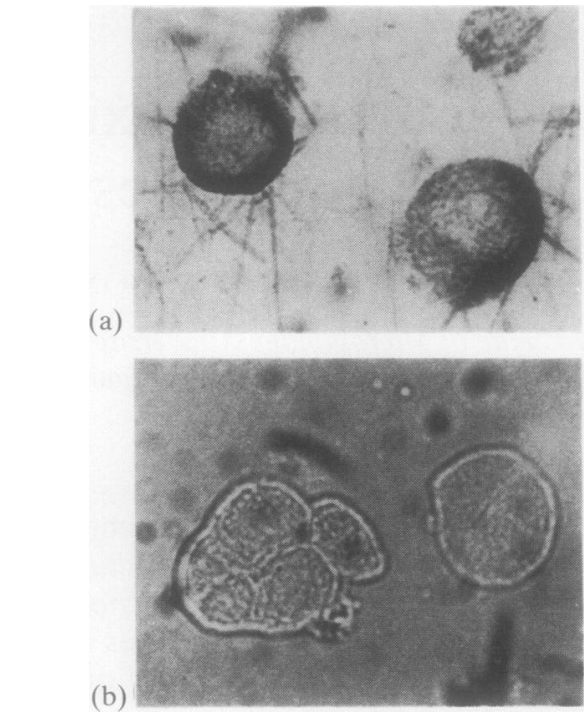

Fig. 1 A typical dark blue cytoplasmic staining of (a) $C$ trachomatis-positive and (b) $C$ trachomatis-negative sera, given by peroxidase reaction.

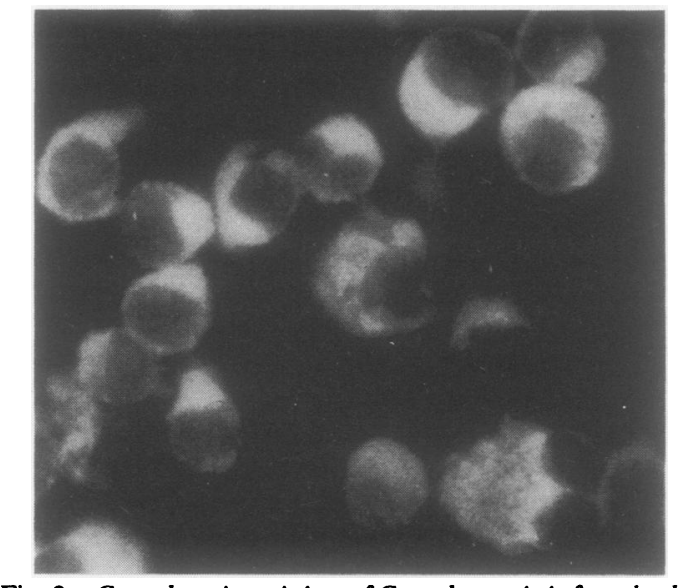

Fig. 2 Cytoplasmic staining of C trachomatis infected cells by indirect immunofuorescence assay.

healthy subjects had titres of 1/8-1/128 by both IPA N and IFA with a mean titre of 18.6 and 21.3 by IPA $\omega$ and IFA respectively. Titres $\geqslant 1 / 32$ were detected 2 in convalescent sera of patients with chlamydial $\stackrel{\circ}{\subset}$ NGU, with a mean titre of 179.2 and 140.8 by IPA and IFA respectively.

\section{Discussion}

With better diagnostic methods, $C$ trachomatis has $\stackrel{\unrhd}{\stackrel{1}{2}}$ been found to be a widespread pathogen, involved 


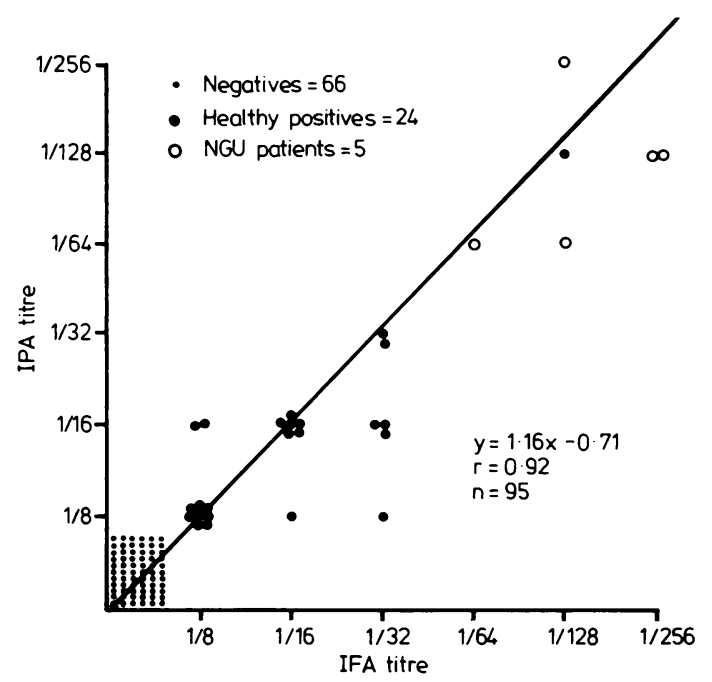

Fig. 3 Comparison of antibody titres detected by indirect immunoperoxidase (IPA) and by direct immunofuorescence (IFA) assay.

in many human infections. In males, $C$ trachomatis is one of the most frequent causes of NGU. ${ }^{1617}$ In females, cervicitis ${ }^{18}$ is the most frequent infection caused by $C$ trachomatis. Chlamydial infection can also induce salpingitis. ${ }^{19}$ There is also some serological evidence that $C$ trachomatis may be linked with infertility in women ${ }^{2021}$ and dysplasia..$^{22-24}$ In addition, inclusion conjunctivitis by $C$ trachomatis is a very common neonatal eye disease, and the commonest in the United States. ${ }^{3}$ The association of an infant distinctive pneumonia syndrome with $C$ trachomatis has also been demonstrated. ${ }^{25}$ At present, there is no ideal method for the serological diagnosis of $C$ trachomatis infections. The two most frequently employed tests are complement fixation (CF) and microimmunofluorescence. The CF test detects the group antigen that is common to all Chlamydia strains, but cannot differentiate typespecific infections. In addition, this test lacks sensitivity in cases of oculogenital $C$ trachomatis infections. The MIF developed by Wang and Grayston is more sensitive than CF and detects type-specific antibodies. This test, however, is only available in a few laboratories due to the difficulties of preparing the reagents. Richmond and Caul' have performed a single-antigen indirect immunofluorescence test which employs $C$ trachomatis (serotype E) infected McCoy cells as the antigen. Subsequently, other authors $^{89}$ performed the single-antigen indirect immunofluorescence test using $C$ trachomatis serotype $\mathrm{L} 2$, which had been estimated previously to cover $95.5 \%$ of the $C$ trachomatis antibodies detected in MIF.
Recently, the reliability of immunoperoxidase technique has been carefully evaluated in comparison with immunofluorescence, ${ }^{13}$ complement fixation, ${ }^{26}$ radioimmunoassay and ELISA $^{27}$ in our laboratory. A complete correlation, as far as positive and negative sera were concerned, was found between the different methods.

In the present study we developed an indirect peroxidase antibody technique to $C$ trachomatis. The IPA described was as sensitive as IFA technique, with a good correlation $(r=0.92)$ between the techniques. The titre was reproducible within a twofold range. The IPA technique could detect either the low level of IgG antibody to $C$ trachomatis in the normal population, as previously described by other authors using MIF $^{28}$ or IFA, ${ }^{8}$ or higher IgG antibody level in patients with chlamydial NGU.

The method is suitable for large scale objective detection of $C$ trachomatis antibodies. The slides, which can be stored at $-70^{\circ} \mathrm{C}$ for months, are easily read by low-power light microscopy. Reagents are easily prepared and since the technique is rapid, simple and sensitive, it has the potential for widespread application.

We thank Mr Loredano Franchi and Mr Vittorio Sambri for excellent technical work.

\section{References}

'Schachter J. Chlamydial infections. $N$ Engl $J$ Med 1978;298:428-35, 490-5, 540-9.

${ }^{2}$ Schachter J, Hanna L, Hill EC, et al. Are chlamydial infections the most prevalent venereal diseases? JAMA 1975;231:1252-5.

${ }^{3} \mathrm{~T}$ ang FF, Chang HL, Huang YT, Wang KC. Trachoma virus in chick embryo. Natl Med J China 1957;43:81-6.

4 Darougar S, Treharne JD. Cell culture methods for the isolation of $C$ trachomatis. A review. In: Mardh PA, Holmes KK, Oriel JD, Piot P, Schachter J. Chlamydial infections. Amsterdam, New York, Oxford: Elsevier Biomedical Press, 1982:265-74.

${ }^{5}$ Wang S-P, Grayston JT. Immunological relationship between genital TRIC, lymphogranuloma venereum and related organisms in a new microtiter indirect immunofluorescence test. Am J Ophthalmol 1970;367-74.

- Thomas BJ, Reeve P, Oriel JD. Simplified serological test for antibodies to Chlamydia trachomatis. J Clin Microbiol 1976;4:6-10.

, Richmond SJ, Caul EO. Fluorescent antibody studies in chlamydial infections. J Clin Microbiol 1975;1:345-52.

- Saikku P, Paavonen J. Single-antigen immunofluorescence test for chlamydial antibodies. J Clin Microbiol 1978;8:119-22.

- Cevenini R, Donati M, Landini MP, Rumpianesi F. Anticorpi nei confronti di Chlamydia trachomatis in pazienti con uretrite non gonococcica e nella popolazione sana, in Italia. Boll Ist Sieroter Milanese 1979;58:406-9.

${ }^{10}$ Cevenini R, Donati M, Rumpianesi F. Elementary bodies as single antigen in a micro-ELISA test for Chlamydia trachomatis. Microbiologica 1981;4:347-51.

"Levy NS, McCormack WM. Detection of serum antibody to chlamydia with ELISA. In: Mardh PA, Holmes KK, Oriel JD, 
Piot $\mathbf{P}$, Schachter J, eds. Chlamydial infections. Amsterdam, New York, Oxford: Elsevier Biomedical Press, 1982:341-4.

${ }^{12}$ Terho P, Meurman O. Chlamydial serum IgG, IgA and local IgA antibodies in patients with genital tract infections measured by solid-phase radioimmunoassay. $J$ Med Microbiol 1981;14:77-87.

${ }^{13}$ Haikin H, Leventon-Kriss S, Sarov I. Antibody to Varicellazoster virus-induced membrane antigen: immunoperoxidase assay with air dried target cells. J Infect Dis 1979;140:601-4.

14 Graham R, Karnowsky MJ. The early states of absorption of injected horseradish peroxidase in proximal tubule of mouse kidney: ultrastructural cytochemistry by a new technique. $J$ Histochem Cytochem 1966;14:291-302.

${ }^{15}$ Cevenini R, Varotti C, Rumpianesi F, Donati M, Tosti A, Negosanti M. Non-gonococcal urethritis: epidemiological and etiological study in Italy. Boll Ist Sieroter Milanese 1980;59:599-603.

${ }^{16}$ Holmes KK, Handsfield HH, Wang S-P, et al. Etiology of nongonococcal urethritis. N Engl J Med 1975;292:1199-205.

17 Cevenini R, La Placa M. Chlamydial infections in Italy. Sex Transm Dis 1981;8:S349-52.

${ }^{18}$ Hilton AL, Richmond SJ, Milna JD, Hindley F, Clarke SKR. Chlamydia $\mathrm{A}$ in the female genital tract. Br J Vener Dis 1974;50:1-10.

${ }^{19}$ Mardh PA, Ripa T, Svennsson L, Westrom L. Chlamydia trachomatis infection in patients with acute salpingitis. $N$ Engl J Med 1977;296:1377-9.

${ }^{20}$ Punnonen R, Terho P, Nikkanen V, Meurman O. Chlamydial serology in infertile women by immunofluorescence. Fertil Steril 1979;31:656-9.

${ }^{21}$ Cevenini R, Possati G. La Placa M. Chlamydia trachomatis infection in infertile woman. In: Mardh PA, Holmes KK, Oriel JD, Piot P, Schachter J, eds. Chlamydial infections. Amsterdam,
New York, Oxford: Elsevier Biomedical Press, 1982:189-92.

${ }^{22}$ Schachter J, Hill EC, King EB, Coleman VR, Jones P, Meyer KF. Chlamydial infection in women with cervical dysplasia. Am J Obstet Gynecol 1975;123:753-7.

${ }^{23}$ Paavonen J, Vesterinen E, Meyer B, et al. Genital Chlamydia trachomatis infections in patients with cervical atypia. Obstet Gynecol 1979;54:289-91.

${ }^{24}$ Cevenini R, Costa S, Rumpianesi F, et al. Cytological and histopathological abnormalities of the cervix in genital Chlamydia trachomatis infections. Br $J$ Vener Dis 1981;57:334-7.

${ }^{25}$ Beem MO, Saxon EM. Respiratory-tract colonization and distinctive pneumonia syndrome in infants infected with Chlamydia trachomatis. N Engl J Med 1977;296:306-10.

${ }^{26}$ Haikin A, Sarov I. Immunoperoxidase antibody to human cytomegalovirus-induced membrane antigen assay in the absence of interfering immunoglobulin $\mathrm{G}$ receptor. Intervirology 1980;14:155-9.

${ }^{27}$ Sarov I, Levy E, Aymard M, et al. Detection of virus-specific IgA antibodies in serum of kidney transplant patients with recurrent cytomegalovirus infection by enzymeimmuno and radioimmunoassay techniques. Clin Exp Immunol 1982;48:321-8.

${ }^{28}$ Wang S-P, Grayston JT, Alexander ER, Holmes KK. Simplified microimmunofluorescence test with trachoma-lymphogranuloma venereum (Chlamydia trachomatis) antigens for use as a screening test for antibody. J Clin Microbiol 1975;1: 250-5.

Requests for reprints to: Dr Roberto Cevenini, Institute of Microbiology, Ospedale S Orsola, 9 Via Massarenti, 40138 Bologna, Italy. 